Original Research Paper

\title{
Paracetamol: A Focus on Dogs
}

\author{
${ }^{1}$ Charbel Fadel, ${ }^{1}$ Irene Sartini and ${ }^{1,2}$ Mario Giorgi \\ ${ }^{1}$ Department of Veterinary Medicine, University of Sassari, Sassari, Italy \\ ${ }^{2}$ Department of Veterinary Sciences, University of Pisa, Pisa, Italy
}

\author{
Article history \\ Received: 14-07-2021 \\ Revised: 28-09-2021 \\ Accepted: 02-10-2021 \\ Corresponding Author: \\ Mario Giorgi \\ Department of Veterinary \\ Sciences, University of Pisa, \\ Pisa, Italy \\ Email: mario.giorgi@unipi.it
}

\begin{abstract}
Paracetamol (APAP) is an aniline analgesic, antipyretic and nonnarcotic. It is an essential drug, widely used in human medicine. In veterinary medicine it has an extra label use in many countries. It is used exclusively in some animals, including dogs. It has a mechanism of action similar to that of NSAIDs, as well as other unique characteristics. A variety of studies on APAP in dogs have been published since its introduction into several clinical practices, covering pharmacokinetics, pharmacodynamics, effectiveness and toxicity when inadvertent or accidental overdosing occurs. When taken at therapeutic doses, APAP has been proven to be a powerful and effective analgesic and antipyretic in dogs, as well as having some anti-inflammatory effects. On the other hand, it should be used with caution. This study is a documentation of the therapeutic, toxic and lethal doses of APAP in dogs, as well as the therapeutic effects, clinical application, mostly for the control of post-operative pain and its toxic effects.
\end{abstract}

Keywords: Dogs, Paracetamol, Pharmacokinetics, Pharmacodynamics, Toxicity

\section{Introduction}

Paracetamol (acetaminophen or APAP) is one of the most commonly used non-prescription drugs in the world, in human medicine. It is easily accessible and reasonably priced. While APAP is less effective as an anti-inflammatory than Non-Steroidal Anti-Inflammatory Drugs (NSAIDs), it acts better as an analgesic (Belay et al., 1999). It also became the primary analgesic and antipyretic drug during the 1980's after the incident of association of aspirin to Reye's syndrome. It was also safer for children and people with ulcers (Belay et al., 1999).

APAP's essential pharmacological effects are only just recently becoming evident and it is now known to be an inhibitor of Prostaglandin (PG) synthesis in cellular systems under certain conditions. But what about its usage in veterinary medicine?

APAP is not licensed for veterinary usage in United States of America, but is certainly used off label. It is licensed in Europe for oral route in dogs (combined with codeine phosphate) and in pigs (Anonymous, 1999). It is used off-label when administered intravenously and as a single therapeutic agent in non-food producing animals (Serrano-Rodríguez et al., 2019). Large interspecies differences in the metabolic fate of APAP have been observed, making it unsuitable for usage in all animals with a limited usage in veterinary medicine because it is contraindicated in cats, ferrets, hedgehogs, sugar gliders and snakes (Johnston et al., 2002). APAP has a very small therapeutic window in cats and toxicity in these species occurs for doses close to the therapeutic range $(10-40 \mathrm{mg} / \mathrm{kg})$. In contrast, toxicity of APAP occurs at higher dosage $(>200 \mathrm{mg} / \mathrm{kg}$ ) in dogs (Savides et al., 1984). It is also generally used in the injectable form in small and large ruminants (Anonymous, 2013).

This review is a snapshot of the current knowledge concerning APAP pharmacology in dogs, focusing on its pharmacokinetics, pharmacodynamics and safety profile.

\section{Nomenclature}

The IUPAC name is N-(4-hydroxyphenyl) acetamide. In the United States, Japan, Canada, Venezuela, Colombia and Iran, acetaminophen is the name commonly used, differently the name paracetamol is commonly used in international venues, according to $\mathrm{WHO}$ chronicles. It is abbreviated as APAP, for acetyl-para-aminophenol, in some places, such as on prescription bottles of painkillers that contain this drug.

\section{Physicochemical Properties}

The compound APAP has a low molecular weight $(151.16 \mathrm{~g} / \mathrm{moL})$. It is an odorless white crystalline solid with a bitter taste (Lewis, 2007). Since it is such a mild acid (pKa 9.0-9.5), it is effectively unionized at physiological $\mathrm{pH}$ levels (Craig, 1990). Its octanol-to-water partition coefficient is 6.2 , which is in the range where 
passive diffusion across cell membranes is possible. Melting point is around $170{ }^{\circ} \mathrm{C}$. It has been found to be very slightly soluble in cold water, but has greater solubility in hot water $\left(14,000 \mathrm{mg} / \mathrm{L}\right.$ at $25^{\circ} \mathrm{C}$, Yalkowsky et al., 2016). It is freely soluble in alcohol, methanol, ethanol, dimethylformamide, ethylene dichloride, acetone, ethyl acetate, slightly soluble in ether and practically insoluble in petroleum ether, pentane and benzene (O'Neil, 2013).

Chemically, APAP is a phenol and is easily oxidized. APAP synthesis involves three steps starting from phenol. First, phenol is converted to nitro phenol via electrophilic aromatic substitution. Then, the nitro group of the para-substituted nitrophenol is reduced to an amine either by sodium-borohydride $\left(\mathrm{NaBH}_{4}\right)$ reduction or direct hydrogenation. Finally, the paraaminophenol is converted to APAP via a reaction with acetic anhydride (Ashutosh, 2004). The chemical characteristics of APAP are summarized in Table 1.

\section{Classification and Differentiation from NSAIDs}

APAP, is an "aniline analgesic" and it is the only drug of this family still used nowadays. It is the active metabolite of phenacetin, which has fallen out of favor due to its carcinogenic potential in therapeutic doses in humans (IARC, 1987).

Despite their comparable pharmacological function, APAP is not included in the NSAIDs class due to the weak anti-inflammatory activity. When applied in recommended doses, it does not induce, unlike NSAIDs, gastrointestinal side effects. Thus, APAP has not been classified as an NSAID in pharmacological textbooks, despite the fact that it has always been discussed alongside these medications, because of their common functions, mentioned in the Table 2.

\section{Pharmacokinetics}

A number of Pharmacokinetic (PK) studies on APAP have been established in dogs. In order to determine the PK profiles, the main analytical technique for APAP concentration detection was the usage of the High Performance Liquid Chromatography (HPLC), coupled to various detectors such as Ultra Violet (UV), Diode Array Detector (DAD) and Mass Spectrometry (MS). The PK were assessed for oral, suppository and intravenous routes of administrations, at different doses. A summary on the analytical methods is described in the Table 3.

\section{Bioavailability}

Dogs and most animal species absorb APAP primarily through the small intestine (Gramatté and Richter, 1994; Yamada et al., 1993; Reppas et al., 1998). Its small size, favorable $\log \mathrm{P}$ and unionized state facilitate diffusion through biological membranes and lead to passive absorption (Swaan et al., 1994). Assuming that the absorption is complete in most species, the first-pass metabolism accounts for the incomplete bioavailability (Rawlins et al., 1977; Perucca and Richens, 1979; Clements et al., 1984). As a result, variations in bioavailability of APAP are most likely due to differences in the degree of first-pass hepatic extraction between organisms and not by absorption. Absorption of readily-soluble drugs is unaffected by gastric and intestinal emptying time (Kelly et al., 2003; Sabnis, 1999). Consequently, the oral bioavailability differences reported in dogs (Neirinckx et al., 2010 44\%; Koyanagi et al., 2014 100\%) might be assumed to be due to diverse metabolisms in canine breeds (1st pass and glucuronidation) (Bock et al., 2002). A recent study (Sartini et al., 2021), in line with the human findings, affirmed that no statistically significant differences were found between fasted and fed dogs regarding bioavailability, $\mathrm{C}_{\max }$ and $\mathrm{T}_{\max }$, thus feeding did not significantly affect the APAP absorption process neither its PK.

A study in which APAP was administered rectally showed that it had a much lower bioavailability than orally administered APAP (Sikina et al., 2018). Although it was rapidly absorbed and eliminated, at a dose of 9.5-14 $\mathrm{mg} / \mathrm{kg}$, it was unlikely to achieve therapeutic concentrations. Further investigations are recommended, such as improving the formulation, increasing the dose (especially that APAP's toxic dose [200 mg/kg] is far away from the suppository dose given) and adding some absorption enhancers (poloxamer 188 and menthol).

In line with these findings, former studies reported a low rectal bioavailability of human suppository formulations, like tramadol, when administered to dogs (Giorgi et al., 2009).

\section{Plasma Protein Binding and Volume of Distribution}

Plasma protein binding of APAP is very low in dogs (Koyanagi et al., 2014). The average protein binding of APAP was between $27 \%$ in young dogs and $23 \%$ in aged dogs. It was also estimated to be $13 \%$ by Duggin and Mudge (1975). As a consequence to this low plasma protein binding, an extensive systemic distribution takes place in dogs, confirmed by the volume of distribution values that ranged from 0.87 to $1.32 \mathrm{~L} / \mathrm{kg}$. The large systemic distribution is also a consequence of the small molecular weight of APAP (Martinez, 1998), combined with its unionized state at all physiological $\mathrm{pH}$ values. Unlike most conventional NSAIDs, APAP's phenolic structure is more lipophilic than the carboxylic acid structure of NSAIDs (Ali et al., 1996). Very low degree of binding to plasma and serum proteins was also confirmed in humans and pigs (Gazzard et al., 1973; Milligan et al., 1994).

\section{Clearance}

Differences in the pharmacokinetic parameters of APAP in different dogs' breeds were found. These differences were assumed to be due to clearance inversely 
related to body weight (Neirinckx et al., 2010). This is not surprising, given the comparatively larger liver and kidney size, the higher relative amount of hepatic enzymes and number of nephrons in proportion to the weight of kidney tissue in smaller animals, as well as the higher cardiac output and the faster blood flow (Lin, 1995; Toutain and Bousquet-Melou, 2004).

The clearance of APAP in dogs ranged from $0.42 \mathrm{~L} / \mathrm{h} / \mathrm{kg}$ (Sartini et al., 2021) to $1.74 \mathrm{~L} / \mathrm{h} / \mathrm{kg}$ (Neirinckx et al., 2010). The clearance was slower in Labrador retriever dogs compared to that found in Beagles, Greyhounds and Galgo Español dogs (Kukanich, 2010; Neirinckx et al., 2010; Koyanagi et al., 2014; Serrano-Rodríguez et al., 2019). This range may appear wide but pharmacokinetic breed-specific differences are well known in canine species (Fleischer et al., 2008; Martinez et al., 2009; Middleton et al., 2017). These variations must be linked to differences in physical features, body weight and animal size, amount of fat reserves, as well as differences in phase I and II enzyme isoforms involved in drug metabolism (MacNaughton, 2003).

It was anticipated that APAP's clearance in dogs is not influenced by changes in urinary $\mathrm{pH}$ within the achievable physiological range since APAP is a weak acid with a $\mathrm{pKa}$ of 9.5 (Duggin and Mudge, 1975). The clearance of APAP depends on urine flow rate but not $\mathrm{pH}$, which was similar to results in humans (Prescott, 1980).

\section{Metabolism, Metabolites and Excretion}

APAP is mainly metabolized in the liver by phase I and II enzymes. After $24 \mathrm{~h}$, most of the drug is recoverable in the urine as conjugates (Savides et al., 1984). Oxidation, reduction and hydrolysis are all possible phase I reactions for APAP in dogs, however, a small proportion only compared to phase II. For the phase II enzymes, in canine species, as in humans, glucuronidation accounts for the majority of the metabolism of APAP (76\%), with a lesser contribution of sulfation and some other pathways (Patel et al., 1992; Prescott, 1983; Savides et al., 1984). Glucuronidation and sulfation yield final products are inactive, nontoxic, hydrophilic and are excreted by the kidneys. However, the small percentage of APAP that is oxidized by Cytochrome P450 (CYP) enzyme transforms to a reactive toxic metabolite $\mathrm{N}$-acetyl-p-benzoquinoneimine (NAPQI) (Davis et al., 1976). At therapeutic doses of APAP, NAPQI binds to Glutathione (GSH) which is a potent tripeptide antioxidant present in all tissues and is then excreted in the urine with the other metabolites, as cysteine and mercapturic acid. The metabolism of APAP in the liver is shown in Fig. 1.

Savides et al. (1984) assessed the presence of the metabolites in dogs' urine, at $100 \mathrm{mg} / \mathrm{kg}$ APAP administration: APAP-glucuronide (75\%), APAP-sulfate (17\%), APAP-cysteine (5\%) and unchanged APAP (2\%). APAP-mercapturic acid accounted for $1 \%$, only after giving a dose of $500 \mathrm{mg} / \mathrm{kg}$. The production of cysteine and mercapturic acid conjugates of APAP is of major toxicological significance (Mitchell et al., 1973; 1974; 1977).

Concerning the excretion, only a very small amount of APAP is bound to plasma proteins and therefore the major part undergoes glomerular filtration. It is reabsorbed in the renal tubules by simple diffusion. The excretory mechanisms for the conjugates are different from those of the parent APAP compound and the excretory pattern of sulphate and glucuronide conjugates are somewhat different from each other (Duggin and Mudge, 1975). For both, clearance is not affected by urine $\mathrm{pH}$ or the rate of urine flow, but is strongly influenced by the concentration of the conjugate in the plasma. Clearance, corrected for plasma binding, shows net tubular secretion at low plasma levels and net reabsorption at high levels. Thus, each conjugate undergoes bidirectional tubular transport.

The sulfate and the glucuronide, both undergo glomerular filtration, being weakly protein bound. At low concentrations in plasma, both compounds are secreted by an active transport process. At higher concentrations, both compounds are reabsorbed. For the reabsorption, APAP itself undergoes reabsorption throughout the nephron while the conjugates are transported in the proximal tubule. The mechanism is explained in details in Duggin and Mudge (1975).

A summary on the studies description, main pharmacokinetic parameters of APAP and safety profiles found in the various literature on dogs, is shown in Table 4 and 5.

Table 1: Chemical characteristics of APAP

\begin{tabular}{ll}
\hline Alternate names & Paracetamol, acetaminophen, p-hydroxyacetanilide, p-acetyl aminophenol, abensanil. \\
Chemical formula & $\mathrm{C}_{8} \mathrm{H}_{9} \mathrm{NO}_{2}$ \\
Appearance & White odorless crystalline powder; large monoclinic prisms from water \\
Molecular weight & $151.16 \mathrm{~g} / \mathrm{mol}$ \\
Melting point & $169-170.5^{\circ} \mathrm{C}$ \\
pH & 5.3 to 6.5 at $25^{\circ} \mathrm{C}$. \\
Density & $1.293 \mathrm{~g} / \mathrm{cc}$ \\
Solubility & Soluble in water $\left(1: 70,1: 20\right.$ at $\left.100^{\circ} \mathrm{C}\right)$, ethanol $(1: 7)$, acetone $(1: 13)$, chloroform $(1: 50)$, glycerol $(1: 40)$, \\
& methanol $(1: 10)$, propylene glycol $(1: 9)$ and solutions of alkali hydroxides; insoluble in diethylether. Slightly \\
& soluble in ether. It is insoluble in petroleum ethers, pentone and benzene. \\
Stability & Dry, pure APAP is stable to $45^{\circ} \mathrm{C}$ \\
Dissociation constant & pKa $=9.0-9.5$ \\
Partition coefficient & Pc $=6.237$ (octanol: pH 7.2 buffer) \\
\hline
\end{tabular}


Table 2: Pharmacological activities of APAP, selective COX-2 inhibitors and non-selective NSAIDs

\begin{tabular}{llll}
\hline Pharmacological activity & APAP & Selective COX-2 inhibitor & Non-selective NSAID \\
\hline Analgesia & Active & Active & Active \\
Antipyresis & Active & Active & Active \\
Anti-inflammatory & Active in mild inflammation & Active & Active \\
Anti-platelet & Low activity & Inactive & Active \\
Damage to stomach and small intestine & Low activity & Low activity & Active \\
Blood pressure & Variable data & Increase & Increase \\
Renal & Lesser effects than both & Impaired function in & Impaired function in \\
& NSAIDs classes & stressed kidneys & stressed kidneys \\
Increased risk of thrombosis & Inactive & Active & Active \\
\hline
\end{tabular}

Table 3: Summary of the analytical methods used in the various literature

\begin{tabular}{|c|c|c|c|c|c|}
\hline Reference & Clean-up & $\mathrm{LOD} \mu \mathrm{g} / \mathrm{mL}$ & $\mathrm{LOQ} \mu \mathrm{g} / \mathrm{mL}$ & $\begin{array}{l}\text { Analytical } \\
\text { method/PK model }\end{array}$ & $\begin{array}{l}\text { Validated following } \\
\text { FDA/EMA guideline }\end{array}$ \\
\hline \multirow[t]{2}{*}{ Sikina et al. (2018) } & Liquid-liquid extraction & NA & NA & UPLC-MS & \\
\hline & & & & Non-compartmental & Yes \\
\hline \multirow[t]{2}{*}{ Sartini et al. (2021) } & Liquid-liquid extraction & 0.01 & 0.05 & HPLC-Diode & \\
\hline & & & & Non-compartmental & Yes \\
\hline \multirow[t]{2}{*}{ Serrano-Rodríguez et al. (2019) } & Solid phase extraction & 0.01 & 0.05 & HPLC-UV & \\
\hline & & & & Bi-compartmental & Yes \\
\hline \multirow[t]{2}{*}{ Neirinckx et al. (2010) } & Liquid-liquid extraction & NA & 0.05 & HPLC-UV & \\
\hline & & & & Non-compartmental & Yes \\
\hline \multirow[t]{2}{*}{ Koyanagi et al. (2014) } & Liquid-liquid extraction & NA & NA & LC-MS/MS & \\
\hline & & & & Non-compartmental & NA \\
\hline \multirow[t]{2}{*}{ Kukanich (2016) } & Solid phase extraction & NA & NA & HPLC-UV & \\
\hline & & & & Non-compartmental & Yes \\
\hline \multirow[t]{2}{*}{ St. Omer and Mohamed (1984) } & NA & NA & NA & Colorimetric method & \\
\hline & & & & -Spectrophotometer & NA \\
\hline \multirow{2}{*}{ Granados et al. (2021) } & Solid phase extraction & 0.01 & 0.05 & HPLC-Diode & $\mathrm{NA}$ \\
\hline & & & & Bi-compartmental & NA \\
\hline
\end{tabular}

NA: Not Available, LOD: Limit Of Detection, LOQ: Limit Of Quantification, FDA: Food and Drug Administration, EMA: European Medicines Agency

Table 4: Summary of the pharmacokinetic and safety studies published in the literatures

\begin{tabular}{|c|c|c|c|c|c|c|c|c|}
\hline Reference & $n$ & Species & Health status & Feed status & ROA and formulation & Dosage schedule & Dose $\mathrm{mg} / \mathrm{kg}$ & Safety data \\
\hline $\begin{array}{l}\text { Sikina et al., } \\
2018\end{array}$ & 26 & Random dogs & $\begin{array}{l}6 \text { Healthy and } \\
20 \text { Ill }\end{array}$ & Random & $\begin{array}{l}\text { Oral tablet (APAP } \\
\text { Plus pharma) } \\
\text { Suppository rectally } \\
\text { (G\&W laboratories) }\end{array}$ & Single dose & $\begin{array}{l}9.3-13 \\
10\end{array}$ & $\begin{array}{l}\text { No visible } \\
\text { side effects }\end{array}$ \\
\hline $\begin{array}{l}\text { Sartini et al., } \\
2021\end{array}$ & 6 & $\begin{array}{l}\text { Labrador } \\
\text { retrievers }\end{array}$ & Healthy & $\begin{array}{l}\text { Fasted } \\
\text { Fed }\end{array}$ & $\begin{array}{l}\text { PO fasted capsule } \\
\text { (Paracetamolodoc) } \\
\text { PO fed capsule } \\
\text { IV (Perfalgan) }\end{array}$ & Single dose & $\begin{array}{l}20 \mathrm{PO} \\
10 \mathrm{IV}\end{array}$ & $\begin{array}{l}\text { No visible } \\
\text { side effects }\end{array}$ \\
\hline $\begin{array}{l}\text { Serrano-Rodríguez } \\
\text { et al., } 2019\end{array}$ & 20 & $\begin{array}{l}10 \text { Beagles and } \\
10 \text { Galgo Espanol }\end{array}$ & Healthy & NA & IV & $\begin{array}{l}\text { Two single } \\
\text { doses }\end{array}$ & $\begin{array}{l}10 \\
20\end{array}$ & $\begin{array}{l}\text { No visible } \\
\text { side effects }\end{array}$ \\
\hline $\begin{array}{l}\text { Neirinckx et al., } \\
2010\end{array}$ & 6 & Beagles & Healthy & Fasted & $\begin{array}{l}\text { IV (Bristol-Myers Squibb) } \\
\text { PO (Ph. Eur. grade) }\end{array}$ & Single dose & $\begin{array}{l}10 \\
10\end{array}$ & $\begin{array}{l}\text { No visible } \\
\text { side effects }\end{array}$ \\
\hline $\begin{array}{l}\text { Koyanagi et al., } \\
2014\end{array}$ & 6 & Beagles & Healthy & Fasted & $\begin{array}{l}\text { IV } \\
\text { PO }\end{array}$ & Single dose & $\begin{array}{l}0.2 \\
1\end{array}$ & $\begin{array}{l}\text { No visible } \\
\text { side effects }\end{array}$ \\
\hline $\begin{array}{l}\text { St. Omer and } \\
\text { Mohamed, } 1984\end{array}$ & 8 & Beagles & Healthy & NA & $\begin{array}{l}\text { IV( } 4 \text { dogs with oral } \mathrm{N}- \\
\text { acetylcystein and } 4 \text { dogs } \\
\text { only with oral saline solution) }\end{array}$ & $\begin{array}{l}\text { Single dose (toxic, } \\
\text { not lethal) }\end{array}$ & 150 & $\begin{array}{l}\text { After 2-3 hours, } \\
\text { animals were weak, } \\
\text { depressed, some } \\
\text { recumbent and some } \\
\text { had methemoglobinemia }\end{array}$ \\
\hline $\begin{array}{l}\text { Granados et al., } \\
2021\end{array}$ & 9 & Beagles & Healthy & $\begin{array}{l}\text { Fasted (12 } \\
\mathrm{h} \text { earlier) }\end{array}$ & IV & Single dose & 20 & No visible side effects \\
\hline
\end{tabular}

PO: Orally, IV: Intravenously, NA: Not Assessed, ROA: Route of Administration, N: Number of individuals 
Table 5: Main pharmacokinetic parameters of APAP found in the literature in dogs

\begin{tabular}{|c|c|c|c|c|c|c|c|}
\hline & $\mathrm{C}_{\max }$ or $\mathrm{C}_{0} \mu \mathrm{g} / \mathrm{mL}$ & $\mathrm{T}_{\max } \mathrm{h}$ & $\mathrm{t}_{1 / 2 \mathrm{kel}} \mathrm{h}$ & $\mathrm{Cl} \mathrm{L/h/kg}$ & AUC Last $\mu \mathrm{g} * \mathrm{~h} / \mathrm{mL}$ & $\mathrm{V}_{\mathrm{ss}} \mathrm{h}^{*} \mu \mathrm{g} / \mathrm{mL}$ & $\mathrm{F} \%$ \\
\hline \multirow[t]{2}{*}{ Sikina et al. (2018) } & PO: 2.69 & 1.04 & 1.81 & - & 7.04 & - & - \\
\hline & Suppository: 0.52 & 0.67 & 3.21 & - & 1.05 & - & - \\
\hline \multirow[t]{3}{*}{ Sartini et al. (2021) } & IV: - & - & 1.35 & 0.42 & 48.01 & 0.87 & - \\
\hline & $\mathrm{PO}_{\text {fasted: }} 11.11$ & 3 & 1.25 & - & 34.61 & - & 72.09 \\
\hline & 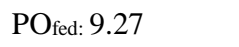 & 2 & 1.77 & - & 40.30 & - & 84.05 \\
\hline \multirow[t]{3}{*}{ Serrano-Rodríguez et al. (2019) } & At $20 \mathrm{mg} / \mathrm{kg}$ : & & & & & & \\
\hline & IV Galgo: - & - & 4.87 & 1.08 & 18.48 & 1.24 & - \\
\hline & IV Beagle: - & - & 2.86 & 1.62 & 12.36 & 1.32 & - \\
\hline \multirow[t]{2}{*}{ Neirinckx et al. (2010) } & IV: - & - & 0.37 & 1.74 & 6.10 & 0.92 & - \\
\hline & PO: 3.08 & 0.25 & 0.38 & - & 6.28 & - & 44 \\
\hline \multirow[t]{2}{*}{ Koyanagi et al. (2014) } & IV: - & - & 0.94 & 0.79 & 0.26 & 0.90 & - \\
\hline & PO: 0.429 & 0.50 & 2.30 & - & 1.50 & - & 108 \\
\hline Kukanich (2016) & PO: 6.74 & 0.85 & 0.96 & - & 13.78 & - & - \\
\hline \multirow[t]{2}{*}{ St. Omer Mohamed (1984) } & $\mathrm{IV}_{\text {with NAC }}-$ & - & 1.06 & 6.52 & 0.39 & 0.59 & - \\
\hline & IV $_{\text {without NAC - }}$ & - & 1.78 & 4.04 & 0.65 & 0.60 & - \\
\hline \multirow[t]{2}{*}{ Granados et al. (2021) } & IV concious - & - & 2.45 & 1.52 & 13.17 & 1.41 & - \\
\hline & IV anesthetized - & - & 3.57 & 1.60 & 12.51 & 1.72 & - \\
\hline
\end{tabular}

$C_{\max }$, peak plasma concentration; $T_{\max }$, time of peak concentration; $t_{1 / 2 k e l}$, terminal half-life; Cl, plasma clearance; $V_{s s}$, volume of distribution at the steady state; F, oral bioavailability. -, not determinable; NAC: N-acetylcystein

Table 6: The variable therapeutic effects of APAP in dogs

\begin{tabular}{|c|c|c|c|}
\hline Cases & Results & Notes & References \\
\hline $\begin{array}{l}\text { Swelling after orthopedic } \\
\text { surgery in dogs }\end{array}$ & $\begin{array}{l}\text { Swelling reduced to very similar extent } \\
\text { by APAP }(33 \%) \text { compared to aspirin } \\
(24 \%) \text { and significantly less pain } \\
(55 \%) \text { vs placebo }\end{array}$ & $\begin{array}{l}\text { APAP } 0.5 \mathrm{~g} \text { was given three times } \\
\text { daily after surgery. No complications in } \\
\text { wound healing occurred }\end{array}$ & Mburu et al. (1988) \\
\hline $\begin{array}{l}\text { Effects on lameness after } \\
\text { experimentally induced } \\
\text { synovitis in dogs }\end{array}$ & $\begin{array}{l}\text { Reduced lameness and pain, but not } \\
\text { as effective as Carprofen }\end{array}$ & $\begin{array}{l}\text { The formulation consisted of APAP } \\
\text { (15.5 to } 18.5 \mathrm{mg} / \mathrm{kg} \text { ) and codeine } \\
\text { (1.6 to } 2 \mathrm{mg} / \mathrm{kg} \text { ) }\end{array}$ & Budsberg et al. (2020) \\
\hline $\begin{array}{l}\text { Postoperative pain control in } \\
\text { dogs following tibial plateau } \\
\text { leveling osteotomy }\end{array}$ & $\begin{array}{l}\text { Hydrocodone-APAP provided better } \\
\text { postoperative analgesia (as determined } \\
\text { by pain score analysis and frequency } \\
\text { of rescue analgesic treatment) compared }\end{array}$ & $\begin{array}{l}\text { Each drug PO every } 8 \mathrm{~h} \text {. Hydrocodone } \\
0.6 \mathrm{mg} / \mathrm{kg} \text { and APAP } 6 \mathrm{mg} / \mathrm{kg} \text {. Tramadol } \\
7 \mathrm{mg} / \mathrm{kg} \text {. The percentage of dogs } \\
\text { to administered tramadol (minor difference) } \\
\text { with treatment failure in both groups was } \\
\text { considered unacceptable }\end{array}$ & Benitez et al. (2014) \\
\hline $\begin{array}{l}\text { Postoperative pain control } \\
\text { in dogs undergoing } \\
\text { ovariohysterectomy }\end{array}$ & $\begin{array}{l}\text { APAP provided equivalent analgesic effects } \\
\text { to those achieved with meloxicam and } \\
\text { carprofen in bitches } 48 \text { hours post- } \\
\text { ovariohysterectomy (gradual reduction } \\
\text { in pain for all groups) }\end{array}$ & $\begin{array}{l}15 \mathrm{mg} / \mathrm{kg} \text { APAP IV group 1, Carprofen } 4 \\
\mathrm{mg} / \mathrm{kg} \text { IV group 2, Meloxicam } 0.2 \mathrm{mg} / \mathrm{kg} \text { IV }\end{array}$ & $\begin{array}{l}\text { Hernández-Avalos } \\
\text { et al. }(2020)\end{array}$ \\
\hline $\begin{array}{l}\text { Peri- and postoperative pain } \\
\text { control in dogs undergoing } \\
\text { soft tissues and orthopedic } \\
\text { surgeries including: Achilles } \\
\text { tendon repair, elbow dysplasia, } \\
\text { hindlimb soft tissue sarcoma } \\
\text { removal, maxillectomy, ear } \\
\text { canal ablation, laryngeal tieback, } \\
\text { dermoid sinus exploration, } \\
\text { hip replacement... }\end{array}$ & $\begin{array}{l}\text { Significantly reduced pain and inflammation. } \\
\text { APAP/codeine combined drug shown to be } \\
\text { very effective post-operatively and showed } \\
\text { non-inferiority (same efficacy) to the } \\
\text { NSAID Meloxicam }\end{array}$ & $\begin{array}{l}\text { APAP+codeine (Pardale-V) once every } 8 \\
\mathrm{~h} \text { orally, starting } 2 \mathrm{~h} \text { before the anesthesia. } \\
\text { Meloxicam } 0.2 \mathrm{mg} / \mathrm{kg} \text { loading dose } 2 \mathrm{~h} \text { before } \\
\text { anesthesia and then } 0.1 \mathrm{mg} / \mathrm{kg} \text { every } 24 \mathrm{~h}\end{array}$ & Pacheco et al. (2020) \\
\hline $\begin{array}{l}\text { Surgically induced myocardial } \\
\text { infarction in dogs }+ \\
\text { exogenously administered } \\
\text { hydrogen peroxide }\end{array}$ & $\begin{array}{l}\text { After APAP administration: reduced } \\
\text { infarctus size, decreased myocardial } \\
\text { tissue necrosis and ischemia and } \\
\text { enhanced reperfusion, less damage to } \\
\text { myofibrils compared to control groups. } \\
\text { Evidence of anti-arrhythmic effects } \\
\text { and heart stabilization too }\end{array}$ & $\begin{array}{l}750 \text { mg APAP IV bolus, divided in } 2 \text { doses. } \\
\text { This Mechanism is mediated by catalase/ } \\
\text { superoxide dismutase. APAP was discovered } \\
\text { to be among the most efficacious cardioprotective } \\
\text { agents. It is a potent anti-oxidant, also reduces } \\
\text { the activity of myeloperoxidase (Brennan } \text { et al., } \\
\text { 2002), which in turn significantly reduces the } \\
\text { oxidation of low-density lipoproteins (LDLs) } \\
\text { in macrophages (Podrez et al., 2000; } \\
\text { Golfetti } \text { et al., 2003). }\end{array}$ & $\begin{array}{l}\text { Merrill et al. (2004. To } \\
\text { also check Merrill et al., } \\
\text { 2001, Merrill 2004; } \\
\text { Nakamoto et al., 1997) }\end{array}$ \\
\hline
\end{tabular}




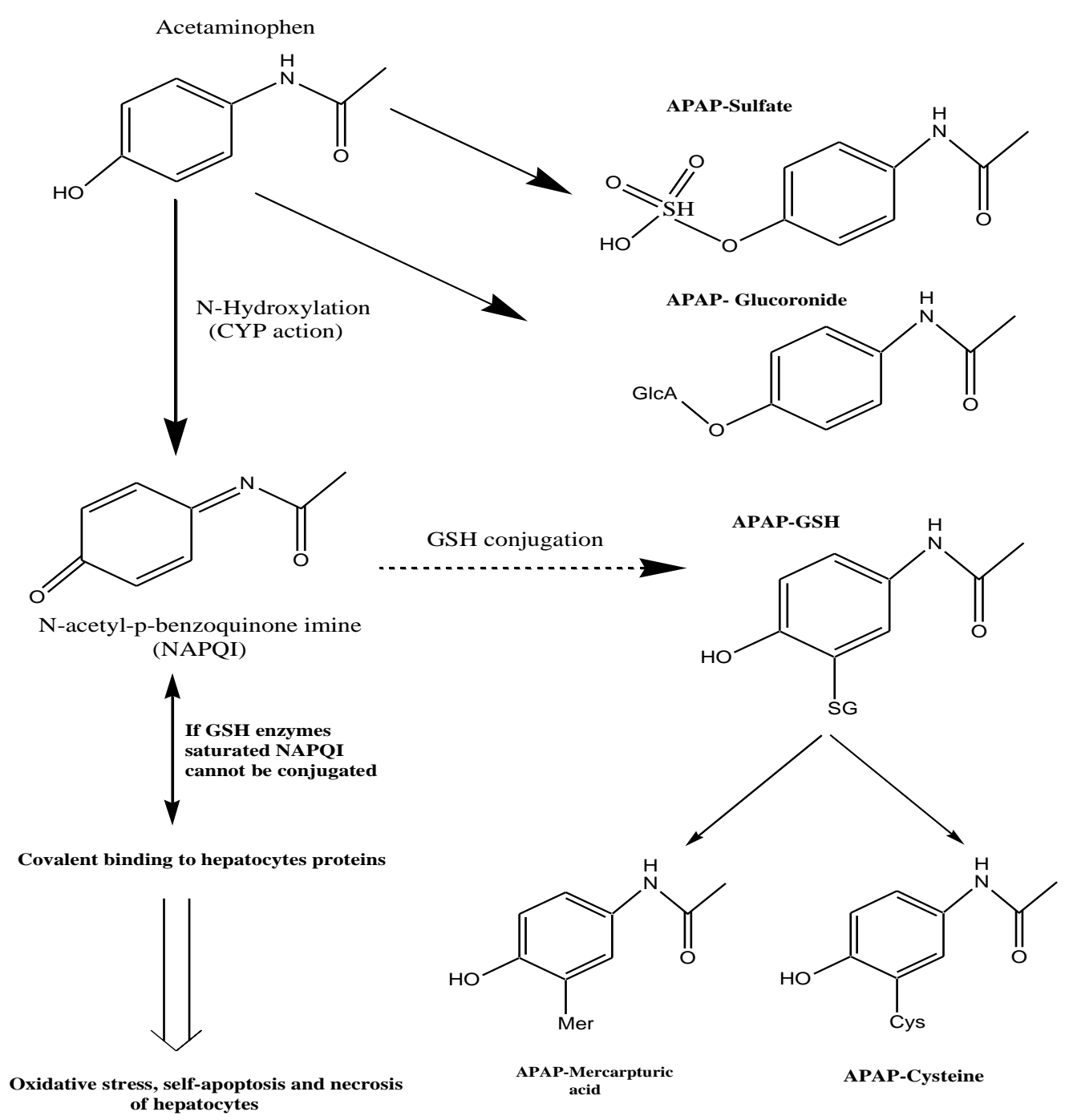

Fig. 1: Metabolic pathways of APAP in mammals

\section{Pharmacodynamics}

The mechanism of action of APAP, which is established mainly in mice, rats and humans, is not fully understood in dogs yet. Thus this review will briefly discuss the findings on APAP's Pharmacodynamics (PD), followed by evidence on the therapeutic effects found in dogs.

APAP is not directly a PGs synthesis inhibitor. APAP inhibits PG activity by acting as a substrate of the peroxidase cycles of COX-1 and COX-2 but, the main impact is frequently on COX-2 (Boutaud et al., 2002; Graham and Scott, 2005; Aronoff et al., 2006; Graham et al., 2013). When concentrations of arachidonic acid are low, the COX-2 pathway is activated in preference to the COX-1 pathway (Graham and Scott, 2005). APAP can inhibit COX, both centrally and peripherally, when ambient concentrations of peroxides are low. However, under pro-inflammatory conditions, when peroxide concentrations are high, APAP is ineffective peripherally and is only active in the brain, where baseline peroxide concentrations are very low. The inhibition of cerebral COX is responsible for the antipyretic effects of APAP (Ouellet and Percival, 2001).

In dogs, a described third isoform, COX-3, has been identified in the cerebral cortex, with minimal amounts found peripherally. This new enzyme was discovered to be inhibited by APAP (Jóźwiak-Bebenista and Nowak, 2014; Chandrasekharan et al., 2002). However, its activity and physiological effects in dogs, rats and humans have been the source of some debate and speculation (Kis et al., 2005; Lucas et al., 2005).

Concerning the central nervous system effect, many studies showed how APAP inhibits central neurotransmitters including substance $\mathrm{P}$ (Crawley et al., 2008; Choi et al., 2001; Björkman et al., 1994) and 
glutamate (Choi et al., 2001; Raffa and Codd, 1996; Mallet et al., 2008) and activates opioidergic system, CB1 cannabinoid receptors, nitric oxid and the 5-HT-3 receptor antagonist (Sandrini et al., 2003; Roca-Vinardell et al., 2003; Bonnefont et al., 2003). Peripherally, APAP prevents the synthesis of PG by a number of peripheral nervous cells and alters the activity of acetylcholine and noradrenaline (Dani et al., 2007; Lee et al., 2007; Graham and Scott, 2005; Graham et al., 2013; Moore et al., 1992).

Regarding the therapeutic effects in dogs, APAP is safe when prescribed at a therapeutic dose and for a limited period of time (Serrano-Rodríguez et al., 2019). In all the studies, it has been noticed that no visible side effects are seen with APAP doses below $100 \mathrm{mg} / \mathrm{kg}$. Many studies have been established, however, further investigations are needed. For instance, the plasma concentration of APAP that can provide analgesia in dogs is unknown. A study published in 2006 reported that a plasma concentration close to $4 \mu \mathrm{g} / \mathrm{mL}$ was sufficient to provide analgesia in humans (Pickering et al., 2006). Despite that the PK/PD relationship for most of the analgesic or an anti-inflammatory drugs obeys to some indirect effects (Sharma and Jusko, 1998), oral acetaminophen in humans suggests to have a minimal hysteresis (nearly a direct effect) (Pickering et al., 2006). Then, if assumed that dogs and humans have the same minimal effective concentration, plasma concentrations of APAP above $4 \mu \mathrm{g} / \mathrm{mL}$ might provide antinociceptive effect for a few hours (Giorgi et al., 2012; Giorgi et al., 2016).

Further evidencing its potential for post-surgical use, the administration of the recommended dose of APAP in dogs $(20 \mathrm{mg} / \mathrm{kg}$ every $8 \mathrm{~h}$ ) (Sartini et al., 2021) can be used instead of NSAIDs, especially if these are contraindicated (Berry, 2015). To note that recently, a recommended drug combination suggested for analgesia in dogs, is an oral opioid formulation plus APAP (Plumb, 2015; Muir, 2015). Opioids that have been combined with APAP for this purpose include codeine, oxycodone and hydrocodone (approved for usage in Europe) (Egger et al., 2014; Benitez et al., 2015; Kukanich, 2010).

APAP is also included in opioid-free anaesthesia protocols, which are often combined with other anesthetic/analgesic drugs, including medetomidine, ketamine, lidocaine, bupivacaine, carprofen and meloxicam in dogs (White et al., 2017).

The documented therapeutic effects of APAP in dogs are summarized in Table 6 .

\section{Toxicology and Pathology}

The clinical signs of APAP toxicity are generally seen with doses above $150 \mathrm{mg} / \mathrm{kg}$ (St. Omer and Mohamed, 1984). APAP is one of the most common household medications and it is not surprising that APAP toxicity, as an unintentional or accidental overdose in dogs, is frequently reported (Caloni et al., 2014).

Toxic effects of APAP in canine species include hepatic damage, kidney failure, serious hematologic disorders and hemoglobin damage (Satirapoj et al., 2007; Pereira et al., 1992). Clinical signs reported in toxic doses were similar and included: Anorexia, weight loss, face swelling, weakness, depression, tachypnea, dyspnea, icterus, vomiting, hypothermia, lethargy and apathy, prolonged capillary refill time, cyanotic or pale mucous membranes and abdominal discomfort (Salem et al., 2010; St. Omer and Mohamed, 1984; Wongnawa et al., 2005; Satirapoj et al., 2007; Savides et al., 1984; Ortega et al., 1985; Villar and Buck, 1998).

The APAP is often poorly used in veterinary medicine because of the wrong belief that it possesses a narrow therapeutic index and several potential increases in toxicity when used in combination with other drugs or natural compounds. Concerning the drug-drug interaction and the resulting toxicity, it was affirmed that maximal enzymatic induction with ethanol in humans is not capable of increasing APAP toxicity when administered within the therapeutic range (Thummel et al., 2000; Rumack, 2004). Phenytoin was also thought to enhance APAP toxicity (Manyike et al., 2000; Brackett and Bloch, 2000). As a CYP3A4 inducer, it does not increase APAP toxicity. Indeed CYP3A4 accounts for only a small portion of APAP metabolism. CYP2E1 is the principal metabolic enzyme for APAP metabolism to NAPQI. Another wrong theory is that barbiturates (i.e., phenobarbital), acting as a pleiotropic inducer of phase I and phase II reactions, can induce all the metabolic enzymes and consequently the CYP2E1. If theoretically this hypothesis has some basis, it has been experimentally assessed that phenobarbital has no effect on any of the processes of APAP-toxic metabolites (Rumack, 2002; 2004).

\section{General Toxicity}

At toxic doses (> $150 \mathrm{mg} / \mathrm{kg}$ ), sulfate and glucuronosyl transferases become saturated and NAPQI production increases. If GSH is depleted to $<20 \%$ of its usual concentration, NAPQI binds covalently to cysteine groups on hepatocellular proteins via cysteine residues, disrupting cellular integrity and yielding hepatocyte necrosis (Pumford et al., 1990). Most of the covalent binding occurs centrolobularly, being preferentially localized in the endoplasmic reticulum and in the enzymes of the cytoplasm. This injury likely takes place very rapidly once GSH depletion is accomplished, leading to the extraordinary levels of aminotransferases and other cellular enzymes, but also a very rapid decline upon cessation of liver injury. Likewise, a free radical formed through the Mixed Function Oxidase (MFO) system causes oxidative damage to cellular molecules (Pereira et al., 1992).

\section{Nephrotoxicity}

Renal damage is a secondary effect described following APAP administration (Salem et al., 2010). Nephrotoxicity is caused by a deacetylation of APAP in the kidney to form p-aminophenol (PAP), a minor 
metabolite, however a potent nephrotoxin (Carpenter and Mudge, 1981; Crowe et al., 1979). This compound may be oxidized to p-benzoquinoneimine, which is very unstable and has a cytotoxicity comparable to NAPQI. Although produced by different metabolic routes, PAP and NAPQI can be produced in the kidney (Bessems and Vermeulen, 2001). These two compounds produced severe congestion of the cortex and medulla, proteinaceous tubular casts and nephrosis after $500 \mathrm{mg} / \mathrm{kg}$ APAP administration (Savides et al., 1984).

A $200 \mathrm{mg} / \mathrm{kg}$ dose produced an increased echodensity in kidney parenchyma that matched with renal damage in dogs. In Salem et al. (2010), renal smears upon cytology showed moderate to severe degree of vacuolation and degeneration of cells and tubular cells degenerated into dark gray amorphous debris representing the necrotic material. This nephrotoxicity is most likely attributed to a depletion of GSH in the renal parenchyma (Loh and Ponampalam, 2006; Kurtovic and Riordan, 2003). On histology, congestion with vasculitis, thickened renal capsule (perinephritis), vacuolation of the glomerular and tubular epithelium, necrosis and perivascular fibrosis were observed. Increased concentrations of Blood Urea Nitrogen (BUN) and serum creatinine reflect this renal damage and were consistent in all reports (Savides et al., 1984; Salem et al., 2010; MacNaughton, 2003; Ortega et al., 1985; Savides and Oehme, 1983; Schlesinger, 1995).

\section{Hematotoxicity}

APAP hematotoxicity in dogs is mainly attributed to PAP (Mc Conkey et al., 2009; Allen, 2003; Taylor and Dhupa, 2003). The toxic metabolites bind to iron and cellular material, resulting in methemoglobinemia, membrane oxidative injury and Heinz bodies formation (Rianprakaisang et al., 2019). The deficiency of arylamine N-acetyltransferase (NAT) activity (polymorphic cytosolic conjugating enzymes) in dogs (and cats) contributes to this species-dependent methemoglobinemia (Mc Conkey et al., 2009).

This blood toxicity does not occur in all cases. It is claimed to be a chronic consequence after a long term administration, however, in many reports it seems to be an acute symptom, with or without hepatotoxicity (Schlesinger, 1995; MacNaughton, 2003).

In all of the references mentioned above for dogs, the hematology repercussions were similar. A mild to severe regenerative anemia, accompanied by a mild to severe stress leukogram were noted. In all reports, significant neutrophilia was consistent. In some cases, there were fragmented red blood cells, poikilocytosis, mild agglutination, spherocytes, acanthocytes, anisocytosis and polychromasia (MacNaughton, 2003; Schlesinger, 1995; Salem et al., 2010; Harvey et al., 1986).

\section{Hepatotoxicity}

The clinical severity of hepatotoxicity is proportional to the dose and ranges from mild to severe acute hepatitis. Liver lesions were similar in most studies (Ortega et al., 1985; Gazzard et al., 1975; Salem et al., 2010) and analogous to morphological changes described by other authors in man and in several animal species (McGregor et al., 2003; Sheen, 2002; Dixon et al., 1975; Mitchell, 1977).

At a dose of $200 \mathrm{mg} / \mathrm{kg}$ of APAP, liver cytology showed damaged hepatocytes distended by multiple lipidic vacuoles of different sizes and the nuclei pushed to the periphery. Histopathology showed a congested liver, mainly in the portal tract, with swelling, centrolobular necrosis and hyperplasia of the bile duct, in Salem et al. (2010). Elevated serum bilirubin concentration (especially unconjugated one), Alanine Transaminase (ALT), Alkaline Phosphatase (ALP), Gamma-Glutamyltransferase (GGT) levels were increased in all the studies (MacNaughton, 2003; Ortega et al., 1985; Savides and Oehme, 1983; Schlesinger, 1995; Savides et al., 1984; Salem et al., 2010).

Dogs receiving $250 \mathrm{mg} / \mathrm{kg}$ showed acute hepatitis and focal necrosis in the centrilobular region with inflammatory infiltrates. Some livers, in addition, showed granulomatous aggregates in acinus and portal space consisting of epithelioid cells with peripheral lymphocyte infiltration (Ortega et al., 1985).

Dogs receiving $500 \mathrm{mg} / \mathrm{kg}$ (lethal dose), all died after $76 \mathrm{~h}$ and showed massive hepatic necrosis extended from terminal hepatic venules to portal spaces, hyperemic sinusoids and hypertrophic sinusoidal cells. Subcellular changes also took place with formation of lamellar structures on the nucleus and mitochondria (Dixon et al., 1975).

Similar liver lesions were also found, with congestion, extensive necrosis, fatty vacuoles at an APAP dose of $3000 \mathrm{mg} / \mathrm{kg}$ (Gazzard et al., 1975). All dogs died in approximately $8 \mathrm{~h}$. Raised levels of arterial ammonia, reduced arterial partial pressure of oxygen, methemoglobinemia and markedly increased Aspartate Aminotransferase (AST) levels occurred for those who survived more than $24 \mathrm{~h}$.

The ingested dose or, more precisely, plasma concentrations of APAP, can predict the incidence and severity of hepatotoxicity. Only when the time of acute ingestion of APAP is known, the Rumack-Matthew nomogram is used to estimate the probability of hepatotoxicity. Plasma concentrations higher than $150 \mu \mathrm{g} / \mathrm{mL}$ suggest possible hepatotoxicity in humans (Rumack and Matthew, 1975). Figure 2 represents the nomogram consisting of a semi-logarithmic curve of plasma APAP levels versus time. 


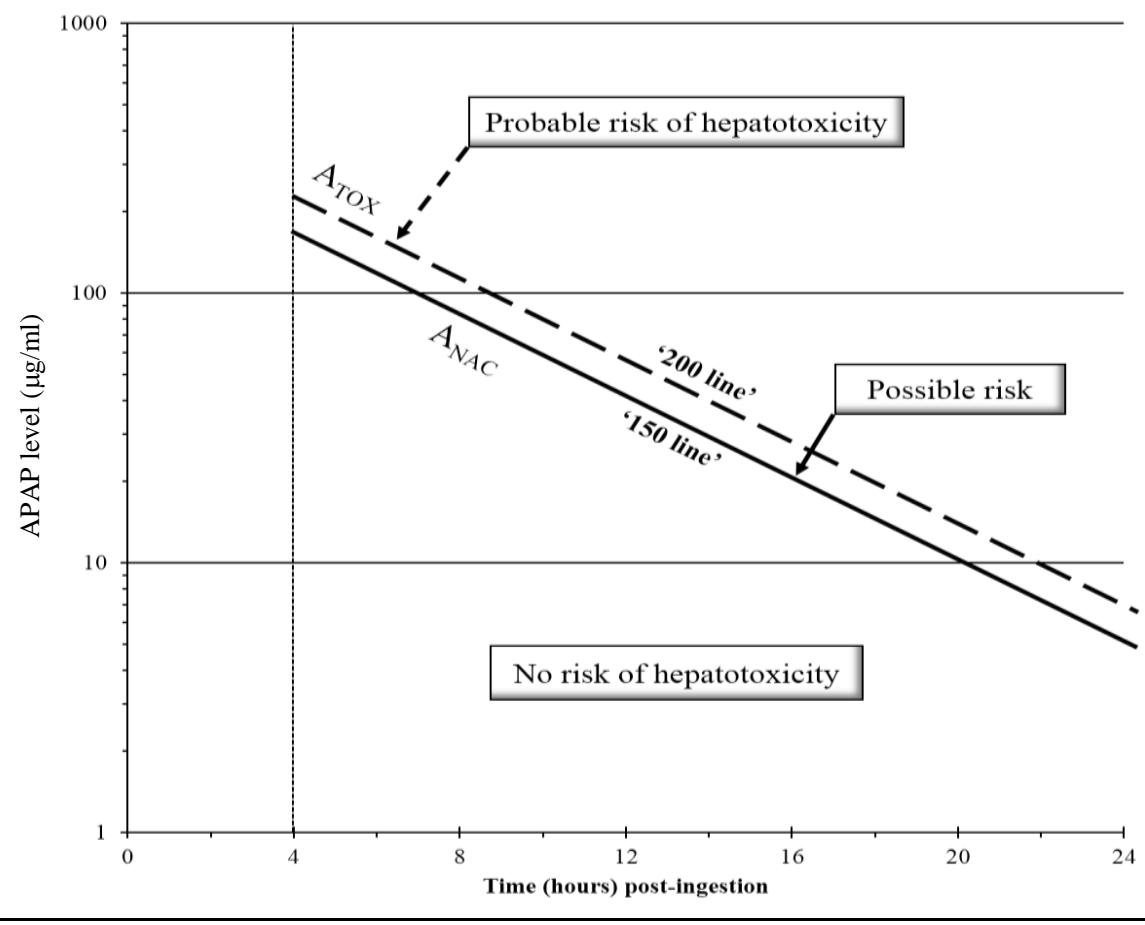

Fig. 2: The Rumack-Matthew Nomogram for APAP poisoning and treatment. After a single acute overdose, the patient's plasma APAP concentration is plotted on the graph using the time from overdose to blood draw. If above the risk line, $150 \mu \mathrm{g} / \mathrm{mL}$, hepatotoxicity is possible and the patient receives acetylcysteine treatment at a dose of $300 \mathrm{mg} / \mathrm{kg}$ body weight. Toxicity is very probable above $200 \mu \mathrm{g} / \mathrm{mL}$. If the plasma concentration is below $150 \mu \mathrm{g} / \mathrm{mL}$, hepatotoxicity is unlikely and no need for treatment

This approach is established in human medicine but with some adjustments it might also fit in canines. Additional tests are recommended if poisoning is confirmed or highly suspected, or if the time of consumption is uncertain. If severe intoxication is suspected, liver enzymes tests and prothrombin time should be conducted. The AST and ALT levels appear to be proportionally related to the stage of poisoning. Bilirubin also increases if the intoxication is severe (O’Malley and O’Malley, 2020).

\section{Antidotes against APAP Toxicity}

$\mathrm{N}$-acetylcysteine (NAC), the precursor of GSH, is a specific antidote against APAP toxicosis in dogs and cats (St. Omer and McKnight, 1980; St. Omer and Mohammad, 1984) and liver necrosis in man (Prescott and Wright, 1973). It is currently the only FDA approved antidote for APAP overdose in humans (Khayyat et al., 2016). NAC restores GSH levels which acts directly on NAPQI to form an acetyl-cysteine conjugate which is excreted in bile. Additionally, NAC supplies mitochondrial energy substrates in the Krebs cycle and restores hepatic ATP levels by providing excess amino-acid and uses it as energy substrates (Saito et al., 2010; Lauterburg et al., 1983).

The minimum recommended clinical dosing schedule of NAC for the treatment of APAP toxicosis in dogs is
$140 \mathrm{mg} / \mathrm{kg}$ orally, repeated every 4 hours for three treatments (St. Omer and McKnight, 1980). It has been reported that NAC alters the pharmacokinetics of APAP (St. Omer and Mohammad, 1984). It decreased the elimination terminal half-life of APAP by $40 \%$ and increased its clearance by $60 \%$. Similar results were obtained in rats (Galinsky and Levy, 1979).

Moreover, it has been demonstrated that cimetidine, an inhibitor of some cytochrome oxidase enzymes, decreases the production of NAPQI by blocking CYP 450 (Ruepp et al., 2002). This would be of benefit to species that develop centrolobular necrosis due to NAPQI, like dogs (Sajedianfard et al., 2009; Rudd et al., 1981; Mitchell et al., 1984).

\section{Conclusion}

APAP, when used in the therapeutic levels, has shown to be a potent and effective analgesic and antipyretic in dogs, with some anti-inflammatory activity. When used in doses below $100 \mathrm{mg} / \mathrm{kg}$, no side effects occur and at recommended therapeutic levels, generally between 10 and $20 \mathrm{mg} / \mathrm{kg}$, is effective for postoperative pain control. It can also be used instead of NSAIDs when these are contraindicated, in combination with opiods and in opioid-free anesthesia surgery protocols. APAP also showed cardioprotective and anti-arrhythmic effects in dogs, nevertheless more details are needed. 
APAP, however, must be used with caution. Doses above $150 \mathrm{mg} / \mathrm{kg}$ are toxic and the repercussions are severe, with hepatotoxicity, hematotoxicity and nephrotoxicity. Doses above $250 \mathrm{mg} / \mathrm{kg}$ can be lethal. Antidotes of APAP such as NAC and cimetidine are shown to effectively reverse, partially, the toxicity.

\section{Acknowledgement}

No third-party funding or support was received in connection with this study or the writing or publication of the review. Authors acknowledge the English editing to Dr Ritta Hanna (Bsc)

\section{Author's Contributions}

Charbel Fadel: Developed the literature search and wrote the draft version of the review. Reviewed and approved the final version of the paper.

Irene Sartini: Contributed in the literature search, planned tables and plots. Verified the consiastency of the information. Reviewed and approved the final version of the paper.

Mario Giorgi: Conceived of the presented idea and supervised the project. Provided critical feedback and helped shape manuscript Reviewed and approved the final version of the paper.

\section{References}

Ali, B. H., Cheng, Z., HADRAMI, G. E., Bashir, A. K., \& McKellar, Q. A. (1996). Comparative pharmacokinetics of paracetamol (acetaminophen) and its sulphate and glucuronide metabolites in desert camels and goats. Journal of veterinary pharmacology and therapeutics, 19(3), 238-244. doi.org/10.1111/j.1365-2885.1996.tb00044.x

Allen, A. L. (2003). The diagnosis of acetaminophen toxicosis in a cat. The Canadian Veterinary Journal, 44(6), 509.

https://www.ncbi.nlm.nih.gov/pmc/articles/PMC340 $185 /$

Anonymous. (1999). Committee for veterinary medicinal products. Paracetamol. Summery reports. www.ema.europa.eu/en/documents/mrlreport/paracetamol-summary-report-committeeveterinary-medicinal-products_en.pdf

Anonymous. (2013). National veterinary drug formulary, second edition. National Centre For Animal Health, Serbithang, Thimphu.

https://www.ncah.gov.bt/Downloads/File_3.pdf

Aronoff, D. M., Oates, J. A., \& Boutaud, O. (2006). New insights into the mechanism of action of acetaminophen: Its clinical pharmacologic characteristics reflect its inhibition of the two prostaglandin $\mathrm{H} 2$ synthases. doi.org/10.1016/j.clpt.2005.09.009
Ashutosh, K., (2004). New Age International (P) limited, Publishers, New Delhi., pp, 83-89. ISBN-10: 978-81224-2488-1.

Belay, E. D., Bresee, J. S., Holman, R. C., Khan, A. S., Shahriari, A., \& Schonberger, L. B. (1999). Reye's syndrome in the United States from 1981 through 1997. New England Journal of Medicine, 340(18), 1377-1382. doi.org/10.1056/NEJM199905063401801

Benitez, M. E., Roush, J. K., McMurphy, R., KuKanich, B., \& Legallet, C. (2015). Clinical efficacy of hydrocodone-acetaminophen and tramadol for control of postoperative pain in dogs following tibial plateau leveling osteotomy. American Journal of Veterinary Research, 76(9), 755-762. doi.org/10.2460/ajvr.76.9.755

Berry, S. H. (2015). Analgesia in the perioperative period. Veterinary Clinics: Small Animal Practice, 45(5), 1013-1027. doi.org/10.1016/j.cvsm.2015.04.007

Bessems, J. G., \& Vermeulen, N. P. (2001). Paracetamol (acetaminophen)-induced toxicity: Molecular and biochemical mechanisms, analogues and protective approaches. Critical reviews in toxicology, 31(1), 55-138. doi.org/10.1080/20014091111677

Björkman, R., Hallman, K. M., Hedner, J., Hedner, T., \& Henning, M. (1994). Acetaminophen blocks spinal hyperalgesia induced by NMDA and substance P. Pain, 57(3), 259-264. doi.org/10.1016/0304-3959(94)90001-9

Bock, K. W., Bock-Hennig, B. S., Münzel, P. A., Brandenburg, J. O., Köhle, C. T., Soars, M. G., ... \& Orzechowski, A. (2002). Tissue-specific regulation of canine intestinal and hepatic phenol and morphine UDP-glucuronosyltransferases by $\beta$-naphthoflavone in comparison with humans. Biochemical pharmacology, 63(9), 1683-1690. doi.org/10.1016/s0006-2952(02)00921-8

Bonnefont, J., Alloui, A., Chapuy, E., Clottes, E., \& Eschalier, A. (2003). Orally administered paracetamol does not act locally in the rat formalin test: Evidence for a supraspinal, serotonin-dependent antinociceptive mechanism. The Journal of the American Society of Anesthesiologists, 99(4), 976-981. doi.org/10.1097/00000542-200310000-00034

Boutaud, O., Aronoff, D. M., Richardson, J. H., Marnett, L. J., \& Oates, J. A. (2002). Determinants of the cellular specificity of acetaminophen as an inhibitor of prostaglandin $\mathrm{H} 2$ synthases. Proceedings of the National Academy of sciences, 99(10), 7130-7135. doi.org/10.1073/pnas.102588199

Brackett, C. C., \& Bloch, J. D. (2000). Phenytoin as a possible cause of acetaminophen hepatotoxicity: Case report and review of the literature. Pharmacotherapy: The Journal of Human Pharmacology and Drug Therapy, 20(2), 229-233. doi.org/10.1592/phco.20.3.229.34774 
Brennan, M. L., Penn, M. S., Van Lente, F., Nambi, V., Shishehbor, M. H., Aviles, R. J., ... \& Hazen, S. L. (2003). Prognostic value of myeloperoxidase in patients with chest pain. New England Journal of Medicine, 349(17), 1595-1604. doi.org/10.1056/NEJMoa035003

Budsberg, S. C., Kleine, S. A., Norton, M. M., Sandberg, G. S., \& Papich, M. G. (2020). Comparison of the effects on lameness of orally administered acetaminophen-codeine and carprofen in dogs with experimentally induced synovitis. American Journal of Veterinary Research, 81(8), 627-634. doi.org/10.2460/ajvr.81.8.627

Caloni, F., Cortinovis, C., Pizzo, F., Rivolta, M., \& Davanzo, F. (2014). Epidemiological study (20062012) on the poisoning of small animals by human and veterinary drugs. Veterinary Record, 174(9), 222-222. doi.org/10.1136/vr.102107

Carpenter, H. M., \& Mudge, G. H. (1981). Acetaminophen nephrotoxicity: Studies on renal acetylation and deacetylation. Journal of Pharmacology and Experimental Therapeutics, 218(1), 161-167. https://citeseerx.ist.psu.edu/viewdoc/download?doi= 10.1.1.909.2676\&rep=rep1\&type $=$ pdf

Chandrasekharan, N. V., Dai, H., Roos, K. L. T., Evanson, N. K., Tomsik, J., Elton, T. S., \& Simmons, D. L. (2002). COX-3, a cyclooxygenase-1 variant inhibited by acetaminophen and other analgesic/antipyretic drugs: Cloning, structure and expression. Proceedings of the National Academy of Sciences, 99(21), 13926-13931. doi.org/10.1073/pnas.162468699

Choi, S. S., Lee, J. K., \& Suh, H. W. (2001). Antinociceptive profiles of aspirin and acetaminophen in formalin, substance $\mathrm{P}$ and glutamate pain models. Brain Research, 921(1-2), 233-239. doi.org/10.1016/s0006-8993(01)03126-2

Clements, J. A., Critchley, J. A., \& Prescott, L. F. (1984). The role of sulphate conjugation in the metabolism and disposition of oral and intravenous paracetamol in man. British journal of clinical pharmacology, 18(4), 481-485.

doi.org/10.1111/j.1365-2125.1984.tb02495.x

Craig, P. N. (1990). Drug compendium. Comprehensive Medicinal Chemistry, 6, 237-991. ISBN-10: 9780128032008.

Crawley, B., Saito, O., Malkmus, S., Fitzsimmons, B., Hua, X. Y., \& Yaksh, T. L. (2008). Acetaminophen prevents hyperalgesia in central pain cascade. Neuroscience letters, 442(1), 50-53. doi.org/10.1016/j.neulet.2008.06.062

Crowe, C. A., Yong, A. C., Calder, I. C., Ham, K. N., \& Tange, J. D. (1979). The nephrotoxicity of paminophenol. I. The effect on microsomal cytochromes, glutathione and covalent binding in kidney and liver. Chemico-biological interactions, 27(2-3), 235-243. doi.org/10.1016/0009-2797(79)90128-5
Dani, M., Guindon, J., Lambert, C., \& Beaulieu, P. (2007). The local antinociceptive effects of paracetamol in neuropathic pain are mediated by cannabinoid receptors. European journal of pharmacology, 573(1-3), 214-215. doi.org/10.1016/j.ejphar.2007.07.012

DAVIS, M., Simmons, C. J., Harrison, N. G., \& WILLIAMS, R. (1976). Paracetamol overdose in man: Relationship between pattern of urinary metabolites and severity of liver damage. QJM: An International Journal of Medicine, 45(2), 181-191. doi.org/10.1093/oxfordjournals.qjmed.a067458

Dixon, M. F., Dixon, B., Aparicio, S. R., \& Loney, D. P. (1975). Experimental paracetamol-induced hepatic necrosis: A light-and electron-microscope and histochemical study. The Journal of pathology, 116(1), 17-29. doi.org/10.1002/path.1711160104

Duggin, G. G., \& Mudge, G. H. (1975). Renal tubular transport of paracetamol and its conjugates in the dog. British journal of pharmacology, 54(3), 359. doi.org/10.1111/j.1476-5381.1975.tb07576.x

Egger, C. M., Love, L., \& Doherty, T. (2014). Pain management in veterinary practice. Ames, Iowa: John Wiley \& Sons Incorporation, pp, 248-262. ISBN-10: 978-0-813-81224-3.

Fleischer, S., Sharkey, M., Mealey, K., Ostrander, E. A., \& Martinez, M. (2008). Pharmacogenetic and metabolic differences between dog breeds: Their impact on canine medicine and the use of the dog as a preclinical animal model. The AAPS journal, 10(1), 110-119. doi.org/10.1208/s12248-008-9011-1

Galinsky, R. E., \& Levy, G. (1979). Effect of Nacetylcysteine on the pharmacokinetics of acetaminophen in rats. Life sciences, 25(8), 693-699. doi.org/10.1016/0024-3205(79)90511-3

Gazzard, B. G., Ford-Hutchinson, A. W., Smith, M. J. H., \& Williams, R. (1973). The binding of paracetamol to plasma proteins of man and pig. Journal of Pharmacy and Pharmacology, 25(12), 964-967. https://academic.oup.com/jpp/articleabstract/25/12/964/6201082

Gazzard, B. G., Hughes, R. D., Mellon, P. J., Portmann, B., \& Williams, R. (1975). A dog model of fulminant hepatic failure produced by paracetamol administration. British journal of experimental pathology, 56(5), 408.

https://www.ncbi.nlm.nih.gov/pmc/articles/pmc2072 783/

Giorgi, M., De Vito, V., Poapolathep, A., Rychshanova, R., Sgorbini, M., \& Owen, H. (2016). Pharmacokinetics and disposition of flupirtine in the horse. The Veterinary Journal, 208, 76-80. doi.org/10.1016/j.tvj1.2015.08.019 
Giorgi, M., Saccomanni, G., Del Carlo, S., Manera, C., \& Lavy, E. (2012). Pharmacokinetics of intravenous and intramuscular parecoxib in healthy Beagles. The Veterinary Journal, 193(1), 246-250. doi.org/10.1016/j.tvj1.2011.11.005

Giorgi, M., Saccomanni, G., Łebkowska-Wieruszewska, B., \& Kowalski, C. (2009). Pharmacokinetic evaluation of tramadol and its major metabolites after single oral sustained tablet administration in the dog: A pilot study. The Veterinary Journal, 180(2), 253-255. doi.org/10.1016/j.tvj1.2007.12.011

Golfetti, R., Rork, T., \& Merrill, G. (2003). Chronically administered acetaminophen and the ischemia/reperfused myocardium. Experimental Biology and Medicine, 228(6), 674-682. doi.org/10.1177/153537020322800605

Graham, G. G., \& Scott, K. F. (2005). Mechanism of action of paracetamol. American journal of therapeutics, 12(1), 46-55. doi.org/10.1097/00045391-200501000-00008

Graham, G. G., Davies, M. J., Day, R. O., Mohamudally, A., \& Scott, K. F. (2013). The modern pharmacology of paracetamol: Therapeutic actions, mechanism of action, metabolism, toxicity and recent pharmacological findings. Inflammopharmacology, 21(3), 201-232. doi.org/10.1007/s10787-013-0172-X

Gramatté T., \& Richter, K. (1994). Paracetamol absorption from different sites in the human small intestine. British journal of clinical pharmacology, 37(6), 608-611. doi.org/10.1111/j.1365-2125.1994.tb04312.x

Granados, M. M., Mengual, C., Navarrete-Calvo, R., Fernández-Sarmiento, J. A., Morgaz, J., QuirósCarmona, S., ... \& Serrano-Rodríguez, J. M. (2021). Influence of general anaesthesia on the intravenous acetaminophen pharmacokinetics in Beagle dogs. Veterinary Anaesthesia and Analgesia, 48(5), 637-644. doi.org/10.1016/j.vaa.2021.02.007

Harvey, J. W., French, T. W., \& Senior, D. F. (1986). Hematologic abnormalities associated with chronic acetaminophen administration in a dog. Journal of the American Veterinary Medical Association, 189(10), 1334-1335.

https://europepmc.org/article/med/3793579

Hernández-Avalos, I., Valverde, A., IbancovichiCamarillo, J. A., Sánchez-Aparicio, P., RecillasMorales, S., Osorio-Avalos, J., ... \& Miranda-Cortés, A. E. (2019). Clinical evaluation of postoperative analgesia and serum biochemical changes of paracetamol compared to meloxicam and carprofen in bitches undergoing ovariohysterectomy. bioRxiv, 785246. doi.org/10.1101/785246

IARC. (1987). International Agency for Research on Cancer. IARC scientific publications (No. 88), Overall evaluations of carcinogenicity: An updating of IARC monographs 1 to 42. Vol. 7, Lyon.
Johnston, J. J., Savarie, P. J., Primus, T. M., Eisemann, J. D., Hurley, J. C., \& Kohler, D. J. (2002). Risk assessment of an acetaminophen baiting program for chemical control of brown tree snakes on Guam: Evaluation of baits, snake residues and potential primary and secondary hazards. Environmental science \& technology, 36(17), 3827-3833. doi.org/10.1021/es015873n

Jóźwiak-Bebenista, M., \& Nowak, J. Z. (2014). Paracetamol: Mechanism of action, applications and safety concern. Acta poloniae pharmaceutica, 71(1), 11-23

Kelly, K., O'mahony, B., Lindsay, B., Jones, T., Grattan, T. J., Rostami-Hodjegan, A., ... \& Wilson, C. G. (2003). Comparison of the rates of disintegration, gastric emptying and drug absorption following administration of a new and a conventional paracetamol formulation, using $\gamma$ scintigraphy. Pharmaceutical research, 20(10), 1668-1673. doi.org/10.1023/a:1026155822121

Khayyat, A., Tobwala, S., Hart, M., \& Ercal, N. (2016). $\mathrm{N}$-acetylcysteine amide, a promising antidote for acetaminophen toxicity. Toxicology letters, 241, 133-142. doi.org/10.1016/j.toxlet.2015.11.008

Kis, B., Snipes, J. A., \& Busija, D. W. (2005). Acetaminophen and the cyclooxygenase-3 puzzle: Sorting out facts, fictions and uncertainties. Journal of Pharmacology and Experimental Therapeutics, 315(1), 1-7. doi.org/10.1124/jpet.105.085431

Koyanagi, T., Yamaura, Y., Yano, K., Kim, S., \& Yamazaki, H. (2014). Age-related pharmacokinetic changes of acetaminophen, antipyrine, diazepam, diphenhydramine and ofloxacin in male cynomolgus monkeys and beagle dogs. Xenobiotica, 44(10), 893901. doi.org/10.3109/00498254.2014.903532

KuKanich, B. (2010). Pharmacokinetics of acetaminophen, codeine and the codeine metabolites morphine and codeine-6-glucuronide in healthy Greyhound dogs. Journal of veterinary pharmacology and therapeutics, 33(1), 15-21. doi.org/10.1111/j.1365-2885.2009.01098.x

KuKanich, B. (2016). Pharmacokinetics and pharmacodynamics of oral acetaminophen in combination with codeine in healthy Greyhound dogs. Journal of veterinary pharmacology and therapeutics, 39(5), 514-517. doi.org/10.1111/jvp.12299

Kurtovic, J., \& Riordan, S. M. (2003). Paracetamolinduced hepatotoxicity at recommended dosage. Journal of internal medicine, 253(2), 240-243. doi.org/10.1046/j.1365-2796.2003.01097.x

Lauterburg, B. H., Corcoran, G. B., \& Mitchell, J. R. (1983). Mechanism of action of N-acetylcysteine in the protection against the hepatotoxicity of acetaminophen in rats in vivo. The Journal of clinical investigation, 71(4), 980-991. doi.org/10.1172/jci110853 
Lee, Y. S., Kim, H., Brahim, J. S., Rowan, J., Lee, G., \& Dionne, R. A. (2007). Acetaminophen selectively suppresses peripheral prostaglandin E2 release and increases COX-2 gene expression in a clinical model of acute inflammation. Pain, 129(3), 279-286. doi.org/10.1016/j.pain.2006.10.020

Lewis, R. J. (2007). Hawley's Condensed Chemical Dictionary 15 th Edition. John Wiley \& Sons, Inc. New York, pp, 11. ISBN-10: 978-0-471-76896-8.

Lin, J. H. (1995). Species similarities and differences in pharmacokinetics. Drug Metabolism and Disposition, 23(10), 1008-1021.

doi.org/10.1186/1747-5341-4-2

Loh, C. S., \& Ponampalam, R. (2006). Nephrotoxicity associated with acute paracetamol overdose: A case report and review of the literature. Hong Kong Journal of Emergency Medicine, 13(2), 105-110. doi.org/10.1177/102490790601300202

Lucas, R., Warner, T. D., Vojnovic, I., \& Mitchell, J. A. (2005). Cellular mechanisms of acetaminophen: Role of cyclo-oxygenase. The FASEB journal, 19(6), 115. doi.org/10.1096/fj.04-2437fje

MacNaughton, S. M. (2003). Acetaminophen toxicosis in a Dalmatian. The Canadian Veterinary Journal, 44(2), 142. doi.org/10.4141/cjas64-022

Mallet, C., Daulhac, L., Bonnefont, J., Ledent, C., Etienne, M., Chapuy, E., ... \& Eschalier, A. (2008). Endocannabinoid and serotonergic systems are needed for acetaminophen-induced analgesia. Pain, 139(1), 190-200. doi.org/10.1016/j.pain.2008.03.030

Manyike, P. T., Kharasch, E. D., Kalhorn, T. F., \& Slattery, J. T. (2000). Contribution of CYP2E1 and CYP3A to acetaminophen reactive metabolite formation. Clinical Pharmacology \& Therapeutics, 67(3), 275-282. https://ascpt.onlinelibrary.wiley.com/doi/abs/10.106 7/mcp.2000.104736

Martinez, M. N. (1998). Special series--use of pharmacokinetics in veterinary medicine. Article III: Physicochemical properties of pharmaceuticals. Journal of the American Veterinary Medical Association, 213(9), 1274-1277. doi.org/10.1021/jm700967e

Martinez, M. N., \& Papich, M. G. (2009). Factors influencing the gastric residence of dosage forms in dogs. Journal of pharmaceutical sciences, 98(3), 844860. doi.org/10.1002/jps.21499

Mburu, D. N., Mbugua, S. W., Skoglund, L. A., \& Lokken, P. (1988). Effects of paracetamol and acetylsalicylic acid on the post-operative course after experimental orthopaedic surgery in dogs. Journal of veterinary pharmacology and therapeutics, 11(2), 163-171. doi.org/10.1111/j.1365-2885.1988.tb00137.x

Mc Conkey, S. E., Grant, D. M., \& Cribb, A. E. (2009). The role of para-aminophenol in acetaminophen-induced methemoglobinemia in dogs and cats. Journal of veterinary pharmacology and therapeutics, 32(6), 585-595. doi.org/10.1111/j.1365-2885.2009.01080.x
McGregor, A. H., More, L. J., Simpson, K. J., \& Harrison, D. J. (2003). Liver death and regeneration in paracetamol toxicity. Human \& experimental toxicology, 22(4), 221-227. doi.org/10.1191/0960327103ht325oa

Merrill, G. F. (2004). Acetaminophen (paracetamol) and injury in the cardiovascular system. Vascular Disease Prevention, 1(2), 123-132. doi.org/10.2174/1567270010401020123

Merrill, G. F., Rork, T. H., Spiler, N. M., \& Golfetti, R. (2004). Acetaminophen and myocardial infarction in dogs. American Journal of Physiology-Heart and Circulatory Physiology, 287(5), H1913-H1920. doi.org/10.1152/ajpheart.00565

Merrill, G., McConnell, P., Vandyke, K., \& Powell, S. (2001). Coronary and myocardial effects of acetaminophen: Protection during ischemiareperfusion. American Journal of Physiology-Heart and Circulatory Physiology. doi.org/10.1152/ajpheart.2001.280.6

Middleton, R. P., Lacroix, S., Scott-Boyer, M. P., Dordevic, N., Kennedy, A. D., Slusky, A. R., ... \& Kaput, J. (2017). Metabolic differences between dogs of different body sizes. Journal of nutrition and metabolism, 2017. doi.org/10.1155/2017/4535710

Milligan, T. P., Morris, H. C., Hammond, P. M., \& Price, C. P. (1994). Studies on paracetamol binding to serum proteins. Annals of clinical biochemistry, 31(5), 492-496. doi.org/10.1177/000456329403100512

Mitchell, J. R. (1977). Host susceptibility and acetaminophen liver injury. https://www.acpjournals.org/doi/pdf/10.7326/00034819-87-3-377

Mitchell, J. R., Jollow, D. J., Potter, W. Z., Davis, D. C., Gillette, J. R., \& Brodie, B. B. (1973). Acetaminophen-induced hepatic necrosis. I. Role of drug metabolism. Journal of Pharmacology and Experimental Therapeutics, 187(1), 185-194. https://jpet.aspetjournals.org/content/187/1/185.short

Mitchell, J. R., McMurtry, R. J., Statham, C. N., \& Nelson, S. D. (1977). Molecular basis for several drug-induced nephropathies. The American journal of medicine, 62(4), 518-526. doi.org/10.1016/00029343(77)90407-7

Mitchell, J. R., Thorgeirsson, S. S., Potter, W. Z., Jollow, D. J., \& Keiser, H. (1974). Acetaminophen-induced hepatic injury: Protective role of glutathione in man and rationale for therapy. Clinical Pharmacology \& Therapeutics, 16(4), 676-684. https://ascpt.onlinelibrary.wiley.com/doi/abs/10.1 002/cpt1974164676

Mitchell, M. C., Schenker, S., \& Speeg, K. V. (1984). Selective inhibition of acetaminophen oxidation and toxicity by cimetidine and other histamine $\mathrm{H} 2$ receptor antagonists in vivo and in vitro in the rat and in man. The Journal of clinical investigation, 73(2), 383-391. https://www.jci.org/articles/view/111223 
Moore, U. J., Seymour, R. A., \& Rawlins, M. D. (1992). The efficacy of locally applied aspirin and acetaminophen in postoperative pain after third molar surgery. Clinical Pharmacology \& Therapeutics, 52(3), 292-296.

https://ascpt.onlinelibrary.wiley.com/doi/abs/10.103 8/clpt.1992.144

Muir III, W. W. (2015). Overview of drugs administered to treat pain. In Handbook of veterinary pain management (pp. 113-141). Mosby.

ISBN-10: 9780323089357.

Nakamoto, K., Kamisaki, Y., Wada, K., Kawasaki, H., \& Itoh, T. (1997). Protective effect of acetaminophen against acute gastric mucosal lesions induced by ischemia-reperfusion in the rat. Pharmacology, 54(4), 203-210. doi.org/10.1159/000139488

Neirinckx, E., Vervaet, C., De Boever, S., Remon, J. P., Gommeren, K., Daminet, S., ... \& Croubels, S. (2010). Species comparison of oral bioavailability, first-pass metabolism and pharmacokinetics of acetaminophen. Research in veterinary science, 89(1), 113-119. doi.org/10.1016/j.rvsc.2010.02.002

O’Malley, G., \& O’Malley, R. (2020). https://www.msdmanuals.com/professional/injuriespoisoning/poisoning/acetaminophen-poisoning

O'Neil, M. J., (2013). The Merck Index - An Encyclopedia of Chemicals, Drugs and Biologicals. Cambridge, UK: Royal Society of Chemistry, pp, 338-339. ISBN-10: 9781849736701.

Ortega, L., Garcia, J. L., Garcia, A. T., Silecchia, G., Arenas, J., Suarez, A., ... \& Cantero, J. B. (1985). Acetaminophen-induced fulminant hepatic failure in dogs. Hepatology, 5(4), 673-676. doi.org/10.1002/hep.1840050425

Ouellet, M., \& Percival, M. D. (2001). Mechanism of acetaminophen inhibition of cyclooxygenase isoforms. Archives of Biochemistry and Biophysics, 387(2), 273-280. doi.org/10.1006/abbi.2000.2232

Pacheco, M., Knowles, T. G., Hunt, J., Slingsby, L. S., Taylor, P. M., \& Murrell, J. C. (2020). Comparing paracetamol/codeine and meloxicam for postoperative analgesia in dogs: A non-inferiority trial. Veterinary Record, 187(8), e61-e61. doi.org/10.1136/vr.105487

Patel, M., Tang, B. K., \& Kalow, W. (1992). Variability of acetaminophen metabolism in Caucasians and Orientals. Pharmacogenetics, 2(1), 38-45. doi.org/10.1097/00008571-199202000-00007

Pereira, L. M., Langley, P. G., Hayllar, K. M., Tredger, J. M., \& Williams, R. (1992). Coagulation factor V and VIII/V ratio as predictors of outcome in paracetamol induced fulminant hepatic failure: Relation to other prognostic indicators. Gut, 33(1), 98-102. https://gut.bmj.com/content/33/1/98.abstract
Perucca, E., \& Richens, A. (1979). Paracetamol disposition in normal subjects and in patients treated with antiepileptic drugs. British journal of clinical pharmacology, 7(2), 201-206. doi.org/10.1111/j.1365-2125.1979.tb00922.x

Pickering, G., Loriot, M. A., Libert, F., Eschalier, A., Beaune, P., \& Dubray, C. (2006). Analgesic effect of acetaminophen in humans: First evidence of a central serotonergic mechanism. Clinical Pharmacology \& Therapeutics, 79(4), 371-378. doi.org/10.1016/j.clpt.2005.12.307

Plumb, D. C. (2015). Plumb's Veterinary Drug Handbook. 8th edPharmaVet Inc Wiley.

Podrez, E. A., Febbraio, M., Sheibani, N., Schmitt, D., Silverstein, R. L., Hajjar, D. P., ... \& Hazen, S. L. (2000). Macrophage scavenger receptor CD36 is the major receptor for LDL modified by monocytegenerated reactive nitrogen species. The Journal of clinical investigation, 105(8), 1095-1108. doi.org/10.1172/JCI8574

Prescott, L. F. (1980). Kinetics and metabolism of paracetamol and phenacetin. British journal of clinical pharmacology, 10(S2), 291S-298S. doi.org/10.1111/j.1365-2125.1980.tb01812.x

Prescott, L. F. (1983). Paracetamol overdosage. Drugs, 25(3), 290-314. doi.org/10.2165/00003495-198325030-00002.

Prescott, L. F., \& Wright, N. (1973). The effects of hepatic and renal damage on paracetamol metabolism and excretion following overdosage.: A pharmacokinetic study. British journal of pharmacology, 49(4), 602-613. doi.org/10.1111/j.1476-5381.1973.tb08536.x

Pumford, N. R., Roberts, D. W., Benson, R. W., \& Hinson, J. A. (1990). Immunochemical quantitation of 3-(cystein-S-yl) acetaminophen protein adducts in subcellular liver fractions following a hepatotoxic dose of acetaminophen. Biochemical pharmacology, 40(3), 573-579. doi.org/10.1016/0006-2952(90)905583

Raffa, R. B., \& Codd, E. E. (1996). Lack of binding of acetaminophen to 5-HT receptor or uptake sites (or eleven other binding/uptake assays). Life sciences, 59(2), PL37-PL40. doi.org/10.1016/0024-3205(96)00273-1

Rawlins, M. D., Henderson, D. B., \& Hijab, A. R. (1977). Pharmacokinetics of paracetamol (acetaminophen) after intravenous and oral administration. European journal of clinical pharmacology, 11(4), 283-286. doi.org/10.1007/BF00607678

Reppas, C., Eleftheriou, G., Macheras, P., Symillides, M., \& Dressman, J. B. (1998). Effect of elevated viscosity in the upper gastrointestinal tract on drug absorption in dogs. European journal of pharmaceutical sciences, 6(2), 131-139. doi.org/10.1016/s0928-0987(97)00077-8 
Rianprakaisang, T., Blumenberg, A., \& Hendrickson, R. G. (2020). Methemoglobinemia associated with massive acetaminophen ingestion: A case series. Clinical Toxicology, 58(6), 495-497. doi.org/10.1080/15563650.2019.1657883

Roca-Vinardell, A., Ortega-Alvaro, A., Gibert-Rahola, J., \& Micó, J. A. (2003). The Role of 5HT1A/BAutoreceptors in the Antinociceptive Effect of Systemic Administration of Acetaminophen. The Journal of the American Society of Anesthesiologists, 98(3), 741-747. doi.org/10.1097/00000542-200303000-00025

Rudd, G. D., Donn, K. H., \& Grisham, J. W. (1981). Prevention of acetaminophen-induced hepatic necrosis by cimetidine in mice. Research communications in chemical pathology and pharmacology, 32(2), 369-372. doi.org/10.1021/tx0155505

Ruepp, S. U., Tonge, R. P., Shaw, J., Wallis, N., \& Pognan, F. (2002). Genomics and proteomics analysis of acetaminophen toxicity in mouse liver. Toxicological sciences, 65(1), 135-150 doi.org/10.1093/toxsci/65.1.135

Rumack, B. H. (2002). Acetaminophen hepatotoxicity: The first 35 years. Journal of toxicology: Clinical toxicology, 40(1), 3-20. doi.org/10.1081/clt-120002882

Rumack, B. H. (2004). Acetaminophen misconceptions. Hepatology, 40(1), 10-15. doi.org/10.1002/hep.20300

Rumack, B. H., \& Matthew, H. (1975). Acetaminophen poisoning and toxicity. Pediatrics.

Sabnis, S. (1999). Factors influencing the bioavailability of peroral formulations of drugs for dogs. Veterinary research communications, 23(7), 425-447. doi.org/10.1023/a:1006321625243

Saito, C., Zwingmann, C., \& Jaeschke, H. (2010). Novel mechanisms of protection against acetaminophen hepatotoxicity in mice by glutathione and $\mathrm{N}$ acetylcysteine. Hepatology, 51(1), 246-254. doi.org/10.1002/hep. 23267

Sajedianfard, J., Saeb, M., \& Edalatpisheh, M. R. (2009). Therapeutic effect of cimetidine on acetaminopheninduced hepatotoxicity in rabbits. Comparative Clinical Pathology, 18(3), 325-328. doi.org/ 10.1007/s00580-008-0806-3

Salem, S. I., Elgayed, S. S., El-Kelany, W. M., \& Abd ElBaky, A. A. (2010). Diagnostic studies on acetaminophen toxicosis in dogs. Global Veterinaria, 5(2), 72-83

Sandrini, M., Pini, L. A., \& Vitale, G. (2003). Differential involvement of central 5-HT 1B and 5-HT 3 receptor subtypes in the antinociceptive effect of paracetamol. Inflammation Research, 52(8), 347-352. doi.org/10.1007/s00011-003-1185-5
Sartini, I., Łebkowska-Wieruszewska, B., Lisowski, A., Poapolathep, A., Cuniberti, B., \& Giorgi, M. (2021). Pharmacokinetics of acetaminophen after intravenous and oral administration in fasted and fed Labrador Retriever dogs. Journal of Veterinary Pharmacology and Therapeutics, 44(1), 28-35. doi.org/10.1111/jvp.12893

Satirapoj, B., P. Lohachit and T. Ruamvang. 2007. Therapeutic dose of acetaminophen with fatal hepatic necrosis and acute renal failure. Journal Medical Association of Thailand, 90: 1244 doi.org/10.1016/j.jceh.2014.05.007

Savides, M. C., \& Oehme, F. W. (1983). Acetaminophen and its toxicity. Journal of Applied Toxicology, 3(2), 96-111. doi.org/10.1002/jat.2550030209

Savides, M. C., Oehme, F. W., Nash, S. L., \& Leipold, H. W. (1984). The toxicity and biotransformation of single doses of acetaminophen in dogs and cats. Toxicology and Applied Pharmacology, 74(1), 26-34. doi.org/10.1016/0041-008x(84)90266-7

Schlesinger, D. P. (1995). Methemoglobinemia and anemia in a dog with acetaminophen toxicity. The Canadian Veterinary Journal, 36(8), 515 https://www.ncbi.nlm.nih.gov/pmc/articles/pmc1686 995/

Serrano-Rodríguez, J. M., Mengual, C., Quirós-Carmona, S., Fernández, J., Domínguez, J. M., Serrano-Caballero, J. M., ... \& del Mar Granados, M. (2019). Comparative pharmacokinetics and a clinical laboratory evaluation of intravenous acetaminophen in Beagle and Galgo Español dogs. Veterinary anaesthesia and analgesia, 46(2), 226-235. doi.org/10.1016/j.vaa.2018.09.042

Sharma, A., \& Jusko, W. J. (1998). Characteristics of indirect pharmacodynamic models and applications to clinical drug responses. British journal of clinical pharmacology, 45(3), 229-239. doi.org/10.1046/j.1365-2125.1998.00676.x

Sheen, C. L., Dillon, J. F., Bateman, D. N., Simpson, K. J., \& Macdonald, T. M. (2002). Paracetamol toxicity: Epidemiology, prevention and costs to the health-care system. Qjm, 95(9), 609-619. doi.org/10.1093/qjmed/95.9.609

Sikina, E. R., Bach, J. F., Lin, Z., Gehring, R., \& KuKanich, B. (2018). Bioavailability of suppository acetaminophen in healthy and hospitalized ill dogs. Journal of veterinary pharmacology and therapeutics, 41(5), 652-658. doi.org/10.1111/jvp.12664

St. Omer, V. V., \& McKnight 3rd, E. D. (1980) Acetylcysteine for treatment of acetaminophen toxicosis in the cat. Journal of the American Veterinary Medical Association, 176(9), 911-913. https://europepmc.org/article/med/7400022

St. Omer, V. S., \& Mohammad, F. K. (1984). Effect of antidotal $\mathrm{N}$-acetylcysteine on the pharmacokinetics of acetaminophen in dogs. Journal of veterinary pharmacology and therapeutics, 7(4), 277-281. 
Swaan, P. W., Marks, G. J., Ryan, F. M., \& Smith, P. L. (1994). Determination of transport rates for arginine and acetaminophen in rabbit intestinal tissues in vitro. Pharmaceutical research, 11(2), 283-287. doi.org/10.1023/a:1018967727156

Taylor, N. S., \& Dhupa, N. (2003). Acetaminophen toxicity in dogs and cats. Compendium of Continuing Education in Dentistry, 12: 160-169. doi.org/10.1111/j.1365-2885.2009.01080.x

Thummel, K. E., Slattery, J. T., Ro, H., Chien, J. Y., Nelson, S. D., Lown, K. E., \& Watkins, P. B. (2000). Ethanol and production of the hepatotoxic metabolite of acetaminophen in healthy adults. Clinical Pharmacology \& Therapeutics, 67(6), 591-599. doi.org/10.1046/j.1365-2125.2000.00167.x

Toutain, P. L., \& Bousquet-Mélou, A. (2004). Plasma clearance. Journal of veterinary pharmacology and therapeutics, 27(6), 415-425. doi.org/10.1111/j.1365-2885.2004.00605.x

Villar, D., Buck, W. B., \& Gonzalez, J. M. (1998). Ibuprofen, aspirin and acetaminophen toxicosis and treatment in dogs and cats. Veterinary and Human Toxicology, 40(3), 156-162. doi.org/10.2307/3428562. JSTOR 3428562
White, D. M., Mair, A. R., \& Martinez-Taboada, F. (2017). Opioid-free anaesthesia in three dogs. Open veterinary journal, 7(2), 104-110. doi.org/10.4314/ovj.v7i2

Wongnawa, M., Thaina, P., Bumrungwong, N., Nitiruangjarat, A., Muso, A., \& Prasartthong, V. (2005). Effect of Phyllanthus amarus Schum. \& Thonn. and its protective mechanism on paracetamol hepatotoxicity in rats. Acta Horticulturae, 680, 195-201. doi.org/10.1016/j.jep.2007.07.037

Yalkowsky, S. H., He, Y., \& Jain, P. (2016). Handbook of aqueous solubility data. CRC press. ISBN-10: 9781439802465.

Yamada, S., Murawaki, Y., \& Kawasaki, H. (1993). Preventive effect of gomisin A, a lignan component of shizandra fruits, on acetaminophen-induced hepatotoxicity in rats. Biochemical pharmacology, 46(6), 1081-1085.

doi.org/10.1016/0006-2952(93)90674-1 